\title{
Changes in immune parameters (lysozyme, IgM, C3) in early life stages and broodstock of Siberian sturgeon, Acipenser baerii
}

\author{
Abdolmajid Valipour, Behrooz Heidari, Mahvash Hadavi, Ayub Yousefi
}

Received - 11 December 2016/Accepted - O6 December 2017. Published online: 31 March 2018; $\odot$ Inland Fisheries Institute in Olsztyn, Poland Citation: Valipour A., Heidari B., Hadavi M., Yousefi A. 2018 - Changes in immune parameters (lysozyme, IgM, C3) in early life stages and broodstock of Siberian sturgeon, Acipenser baerii - Fish. Aquat. Life 26: 21-30.

\begin{abstract}
In the present study, lysozyme, immunoglobulin M (IgM), and complement component 3 (C3) were measured in unfertilized and fertilized eggs, two week post fertilization (WPF) larvae and 1, 2, 4, 6, and 12 month post fertilization (MPF) juveniles and the female broodstock of Siberian sturgeon, Acipenser baerii Brandt. The lysozyme level was measured with the turbidimetric method and IgM and C3 levels were measured with the ELISA method. The results showed that the lysozyme level decreased significantly from the unfertilized eggs to the 2-week-old larvae, and then it increased until 2 MPF. Significant changes in lysozyme levels were not observed from the $2 \mathrm{MPF}$ juveniles to the broodstock. The IgM level decreased significantly from the unfertilized eggs to the 2 WPF larvae, then it increased until the 2 MPF, and, finally, it revealed a significant decrease in $4 \mathrm{MPF}$ juveniles. Significant variations of $\mathrm{C} 3$ were found from the unfertilized eggs to the 2 MPF juveniles. Additionally, there were no significant variations in IgM or C3 in 4 to $12 \mathrm{MPF}$ juveniles or in the female broodstock. The results indicate that two weeks post fertilization can be an immunologically sensitive period in early life stages of Siberian sturgeon.
\end{abstract}

Keywords: Acipenseridae, immunity, larvae, egg, juvenile

A. Valipour, B. Heidari [ $\sqsubseteq]$, M. Hadavi

Department of Biology, Faculty of Science, University of Guilan, Rasht, Iran and Caspian Sea Basin Research Center, Department of Marine Sciences, University of Guilan, Rasht, Iran

Namjoo St. Faculty of Science, Rasht, Iran, Postal Code: 4193833697

e-mail: Bheidari@guilan.ac.ir, Behrooz1072@yahoo.com

Tel: +981333243630, Fax: +981333220066

A. Yousefi

International Sturgeon Research Institute, Rasht, Iran

\section{Introduction}

Like in other vertebrates, immunity in fishes plays an important role in protecting animals against diseases and is divided into innate and adaptive immunity (Kumari et al. 2006). Lysozyme is one of the most important parameters of innate immunity, and it is involved in the destruction of the peptidoglycan layer of cell walls in gram-positive bacteria (Alexander and Ingram 1992). In larval stages of fishes, lysozyme is found in very early stages (Takemura 1996) when specific immunological responses are not yet developed (Cecchini et al. 2000). The complement system is an essential component of innate immunity, which is comprised of about 35 individual proteins (Sahu and Lambris 2001). The complement component 3 (C3) plays a central role in the activation of both classical and alternative complement system pathways. The roles of the complement system are numerous, but generally, they are known by creating pores in the membrane surface of cells (Fearon and Locksley 1996, Sahu and Lambris 2001). The immunoglobulin $\mathrm{M}(\mathrm{IgM})$ is the most important type of antibody in adaptive immunity, and it is the first antibody to appear during the developmental stages of fertilized eggs in fish (Ingram 1980). Maternal IgM has been detected in the eggs of several fish species such as plaice, Pleuronectes platessa L. (Bly et al. 1986), 
tilapia, Oreochromis mossambicus (Peters) (Mor and Avtalion 1990, Takemura 1993), carp, Cyprinus carpio L. (Suzuki et al. 1994), and sea bass, Dicentrarchus labrax (L.) (Picchietti et al. 2004).

Lysozyme, C3, and IgM have also been detected in oocytes, fertilized eggs, and larval stages of several fish species, for example, in the eggs of Coho salmon (Oncorhynchus kisutch (Walbaum)) and other salmonids, sea bass, tilapia, and other species (Magnadottir et al. 2005). The ontogeny of C3 in Atlantic cod (Gadus morhua L.) and Atlantic halibut (Hippoglossus hippoglossus (L.)) at several developmental stages after hatching has been studied with immunohistochemical techniques (Lang et al. 2004a, 2004b). In Atlantic halibut, C3 was detected in several cells and tissues at developmental stages from days 5 to 99 after hatching (Lang et al. 2004a). Western blotting of homogenized unfertilized and newly fertilized eggs (0.5 days degrees, do) in spotted wolffish (Anarhichas minor Olafsen) revealed a $65-\mathrm{kDa}$ protein band corresponding to the beta-chain of C3 (Ellingsen et al. 2005). Quantitative PCR has been performed to detect the onset of C3 transcription in embryos of rainbow trout (Oncorhynchus mykiss (Walbaum)) eggs (Magnadottir et al. 2005). In sea bass, IgM was detected from 50 DPH (days post hatching) onward (Breui et al. 1997, Dos Santos et al. 2000), and spotted wolffish showed IgM producing cells between 1 and 4 weeks post hatching (Grontvedt and Espelid 2003).

Variations of immune parameters including lysozyme and C3 in larval stages of some teleost species has been studied (Takemura and Takano 1995, Takemura 1996, Cecchini et al. 2000, Lange et al. 2004a, 2004b, Wang et al. 2009), but in sturgeons it has not been sufficiently investigated. The Acipenseridae family occupies a critical position in fish phylogeny (Ludwig 2006, Hurley et al. 2007), and many species of sturgeon are also economically important in aquaculture. Siberian sturgeon, Acipenser baerii Brandt, from the Acipenseridae family is a freshwater fish that inhabits large Siberian rivers such as the $\mathrm{Ob}$, Yenisei, Lena, and Kolyma. The most commonly used species for the sturgeon cultivation in different countries is Siberian sturgeon, which is presently reared in 22 countries reaching a total production of about 8,800 tonnes per year (Bronzi et al. 2011).

Larval culture is considered to be one of the most critical and difficult stages in intensive sturgeon farming, and it is often accompanied by high mortality rates during and after yolk sac absorption and the onset of exogenous feeding (Mohler et al. 2000). Increasing fish immunity against pathogens, especially in early developmental stages, through detailed study of immune system parameters can enhance larval culture efficiency. Hence, the aim of this study was to evaluate changes in the most important parameters of immunity (IgM, C3, and lysozyme) in early life stages, unfertilized eggs, the larval phase with endogenous feeding ( 24 hours post fertilization (HPF), 2 weeks post fertilization (WPF)), and the juvenile phase with exogenous feeding $(1,2,4,6$ and $12 \mathrm{MPF}$ ) and to compare them with Siberian sturgeon broodstock.

\section{Materials and methods}

\section{Fish and rearing condition}

The animals examined in the present study were produced through the assisted propagation of Hungarian broodstocks at the Shahid Dr. Beheshti Sturgeon Fish Propagating and Rearing Complex, Rasht, Guilan.

\section{Broodstock and eggs}

The sturgeon breeding and fingerling production season is restricted to the period from March to July in the hatcheries of the south Caspian Sea. Hence, the broodstock of Siberian sturgeon $(n=5)$ was collected from breeding ponds (diameter $4 \mathrm{~m}$ and water depth $1.2 \mathrm{~m}$ ). Female broodstock was anesthetized with clove oil (150-200 ppm) for $10 \mathrm{~min}$. Blood samples were taken from the caudal vein with $5 \mathrm{ml}$ heparinized disposable syringes fitted with 23 gauge needles and then centrifuged at $906 \mathrm{rcf}$ for $10 \mathrm{~min}$ at $4^{\circ} \mathrm{C}$ and finally, the plasma was frozen at $-70^{\circ} \mathrm{C}$ until parameter analysis. The total length and weight of 
the broodstock were measured with a tape measure and digital scale, respectively.

In preparation for fertilization, the broodstock fish were injected with luteinizing hormone releasing hormone (LHRH-A $\mathrm{A}_{2} ; 4 \mathrm{mg}$ per $\mathrm{kg}$ of body weight) twice. Based on the position of the germinal vesicle (GV), the ripe eggs were collected by cutting the end of the oviduct of the broodstock fish with a specially devised surgical scalpel (Bani and Banan 2010). Some unfertilized eggs ( $\mathrm{n}=5$ and $5 \mathrm{~g}$ per individual) were separated for the immune parameter analysis and the others were fertilized with the semi-dry method by adding sperm. The fertilizing eggs were diluted with hatchery water to avoid polyspermy. Twenty-four hours post fertilization (HPF), a certain amount of the fertilized eggs ( $\mathrm{n}=5$ and $5 \mathrm{~g}$ per individual) was taken for parameter analysis.

In order to determine the fertilization percentage, 100 eggs in the second division (about 3.5 hours after fertilization) were taken randomly and calculated using a stereo microscope (Nikon MSZ 800). Unfertilized and fertilized eggs were transferred to the Marine Biology Laboratory at the University of Guilan. Then, they were rinsed three times with sterile phosphate-buffered saline (PBS; pH 7.2). Finally, after measuring the diameter and weight of 5 eggs with a coulisse and a digital scale, respectively, the eggs were immediately homogenized with PBS (Weight 1: Volume 10) for $1 \mathrm{~min}$ and centrifuged at $3622 \mathrm{rcf}$ for $20 \mathrm{~min}$ at $4^{\circ} \mathrm{C}$. The supernatant was pooled, aliquoted, and stored at $-70^{\circ} \mathrm{C}$ until the analysis of immune parameters.

\section{Larvae and juveniles}

The fertilized eggs were maintained in incubators (water volume $3 \mathrm{~L}$; water depth $15 \mathrm{~cm}$ ). After the eggs hatched, the larvae with yolk sacs were transported to fiberglass vases (water volume $3 \mathrm{~L}$; water depth 15 $\mathrm{cm})$. After yolk absorption, these larvae were fed with artemia, daphnia, chironomid larvae, and concentrated pellets 4 times per day at a ratio of $15-20 \%$ of body weight. The larvae and juveniles at ages of 2 WPF and 1, 2, 4, 6, 12 MPF were collected randomly
( $\mathrm{n}=5$ at each stage) from the rearing tanks and frozen immediately at $-70^{\circ} \mathrm{C}$ until the analysis of immune parameters. After biometric measurements were taken of the samples, the whole body was homogenized with PBS (pH 7.2, $0.1 \mathrm{M}$ ) (W1: V10) for $1 \mathrm{~min}$ and then centrifuged at $3622 \mathrm{rcf}$ for $20 \mathrm{~min}$ at $4^{\circ} \mathrm{C}$ and finally, the supernatant was frozen at $-70^{\circ} \mathrm{C}$ until analysis. The water quality parameters including temperature $\left(16.1 \pm 1.1^{\circ} \mathrm{C}\right)$, dissolved oxygen $\left(8.2 \pm 0.1 \mathrm{mg} \mathrm{L}^{-1}\right)$, ammonia $\left(0.1 \pm 0.001 \mathrm{mg} \mathrm{L}^{-1}\right)$, nitrites $(0.1 \pm 0.02 \mathrm{mg}$ $\left.\mathrm{L}^{-1}\right)$, $\mathrm{pH}(7.5 \pm 0.4)$, and salinity $<1$ ppt were monitored daily during the experiment.

\section{Lysozyme activity}

The lysozyme activity was measured using the turbidimetric method described by Ellis with some modifications (Ellis 1990) using $100 \mu \mathrm{l}$ of the supernatant of homogenized samples and plasma that were mixed with $300 \mu \mathrm{l}$ of a $0.2 \mathrm{mg} \mathrm{ml}^{-1}$ suspension of Micrococcus luteus (Sigma-Aldrich, St. Louis, MO, USA) in $200 \mu \mathrm{l}$ of $0.1 \mathrm{M}$ PBS, $\mathrm{pH}$ 6.2. The absorbance at $450 \mathrm{~nm}$ was measured every $15 \mathrm{sec}-$ onds to 180 seconds using a spectrophotometer (Ultaspect 3000, Pharmacia Biotech). One unit of lysozyme activity was equal to a decrease in turbidity of 0.001 per minute at $450 \mathrm{~nm}$ at $\mathrm{pH} 6.2$ and $25^{\circ} \mathrm{C}$ under the specified conditions. The lysozyme activity was obtained using the following formula (Chakraborti et al. 2010):

$$
\begin{aligned}
& \text { - Lysozyme Activity }\left(\text { Units } \mathrm{mg}^{-1}\right)=\Delta \mathrm{OD} \times \mathrm{Df} \\
& \quad /\left(\min \times 0.001 \times \mathrm{V}_{\mathrm{S}}\right),
\end{aligned}
$$

where, $\Delta \mathrm{OD}=$ decrease of optical density, $\mathrm{Df}=$ dilution factor, $V_{S}=$ enzyme volume, $0.001=$ one unit of lysozyme activity. The lysozyme activity expressed as $\mathrm{U}$ per milligram $\left(\mathrm{U} \mathrm{mg}^{-1}\right)$ of total protein was measured according to the Bradford method (Bradford 1976).

\section{Complement component C3 assay}

The concentration of C3 was measured using a sandwich ELISA (enzyme-linked immunosorbent assay) with the Fish ELISA kit (Hangzhou Eastbiopharm Co., Ltd.) (Nash et al. 2000). Briefly, $40 \mu \mathrm{l}$ of samples were 
added to the well that was pre-coated with the fish complement component C3 monoclonal antibody. Then, 10 $\mu \mathrm{l}$ of C3 antibodies labeled with biotin was added and combined with $50 \mu \mathrm{l}$ of Streptavidin-HRP to form immune complexes after incubation at a temperature of $37^{\circ} \mathrm{C}$ for $1 \mathrm{~h}$. After washing to remove the uncombined enzyme, $50 \mu \mathrm{l}$ of Chromogen solution A and B was added and incubated at a temperature of $37^{\circ} \mathrm{C}$ for 10 $\mathrm{min}$. The color of the liquid was changed to blue and finally, under the effect of the stopping solution $(50 \mu \mathrm{l}$ of sulfuric acid), the color became yellow. Optical density (OD) was measured using an ELISA reader (ELX800 Absorbance Reader, BioTek, USA) at $450 \mathrm{~nm}$. According to the standard concentration and the corresponding OD values, the standard curve linear regression equation was calculated. Then the OD values of the samples were applied to the regression equation to calculate the corresponding sample concentration. The blank well (containing only Chromogen solution A and $B$ and the stop solution) and the standard well (containing only Streptavidin-HRP) were used as negative and positive controls, respectively. Inter- and intra-assay coefficients of variation (CV) were $<12 \%$ and $<10 \%$, respectively. The C3 values were expressed as $\mathrm{mg} \mathrm{dl}^{-1}$.

\section{Immunoglobulin M (IgM) assay}

IgM, like complement component C3, was measured with a separated Eastbiopharm ELISA kit based on the sandwich ELISA method (Nash et al. 2000).

\section{Statistical analysis}

The raw data on lysozyme, IgM, and complement component C3 of the samples were tested initially assuming the normality and homogeneity of variance. The Kolmogorov-Smirnov test was used to assess the normality of distributions. Normalized data passed Levene's test for homogeneity of variance before one-way analysis of variance (ANOVA). In cases in which assumptions were met, the data was analyzed for the unfertilized and fertilized eggs, $2 \mathrm{WPF}$, and 1 , 2, 4, 6, $12 \mathrm{MPF}$ with one-way analysis of variance (ANOVA) in SPSS (Version 20, IBM). The Duncan post hoc test was used to identify significant differences among the various means of the immune parameters from the unfertilized eggs to the female broodstock of Siberian sturgeon at a confidence level of $95 \%$. All experiments were performed in triplicate, and the values were expressed as mean \pm SD.

\section{Results}

The biometric data of early life stages of Siberian sturgeon and broodstock are presented in Table 1.

\section{Lysozyme}

Lysozyme activity showed significant changes in Siberian sturgeon from unfertilized eggs to $12 \mathrm{MPF}$ juveniles $(\mathrm{P}<0.05)$ (Fig. 1). Lysozyme activity showed a significant decrease from unfertilized eggs to 2 WPF larvae $(\mathrm{P}<0.05)$, and then it increased until 2 MPF (Fig. 1). The maximum and minimum activity of lysozyme levels were observed in unfertilized eggs $\left(198.23 \pm 71.21 \mathrm{U} \mathrm{mg}^{-1}\right)$ and $2 \mathrm{WPF}$ old larvae $\left(49.22 \pm 15.60 \mathrm{U} \mathrm{mg}^{-1}\right)$. There were no significant variations in lysozyme activity between the juvenile aged 4-12 MPF and the plasma of female broodstock $\left(116.39 \pm 13.43 \mathrm{U} \mathrm{mg}^{-1}\right)(\mathrm{P}>0.05)$.

\section{Immunoglobulin M (IgM)}

Significant changes were noted in IgM levels in Siberian sturgeon from unfertilized eggs to $12 \mathrm{MPF}$ juveniles $(\mathrm{P}<0.05)$ (Fig. 2). The IgM level decreased significantly from unfertilized eggs to $2 \mathrm{WPF}$ larvae $(\mathrm{P}$ $<0.05$ ), and then it increased until $2 \mathrm{MPF}$ until it decreased remarkably until 12 MPF $(\mathrm{P}<0.05)$ (Fig. 2). There were no significant variations of IgM between juveniles aged $4-12 \mathrm{M}$ and the plasma IgM of the female broodstock $\left(8.05 \pm 0.52 \mathrm{mg} \mathrm{dl}^{-1}\right)(\mathrm{P}>0.05)$. 
Table 1

The biometric data of Siberian sturgeon sampled at different life stages

\begin{tabular}{llll}
\hline \hline Sampling time & Samples & Diameter/Length $(\mathrm{mm})$ & Weight $(\mathrm{g})$ \\
\hline \hline 18 March 2014 & Unfertilized eggs & $3.10 \pm 0.10$ & $0.01 \pm 0.00$ \\
6 April 2014 & Fertilized eggs & $3.50 \pm 0.10$ & $0.01 \pm 0.00$ \\
20 April 2014 & $2 \mathrm{WPF}^{*}$ larvae & $17.33 \pm 0.76$ & $0.17 \pm 0.00$ \\
6 May 2014 & $1 \mathrm{MPF} \#$ juveniles & $30.67 \pm 0.58$ & $0.320 \pm 0.01$ \\
6 June 2014 & 2 MPF juveniles & $82.67 \pm 2.58$ & $2.20 \pm 0.03$ \\
6 August 2014 & 4 MPF juveniles & $148.67 \pm 14.74$ & $22.07 \pm 1.83$ \\
7 October 2014 & $6 \mathrm{MPF}$ juveniles & $287.67 \pm 13.81$ & $66.30 \pm 12.76$ \\
6 April 2015 & 12 MPF juveniles & $319.67 \pm 1356$ & $94.43 \pm 6.46$ \\
16 March 2015 & Broodstock fish & $650.00 \pm 50.00$ & $7400.00 \pm 950.00$ \\
\hline \hline
\end{tabular}

* weeks post fertilization; \# months post fertilization

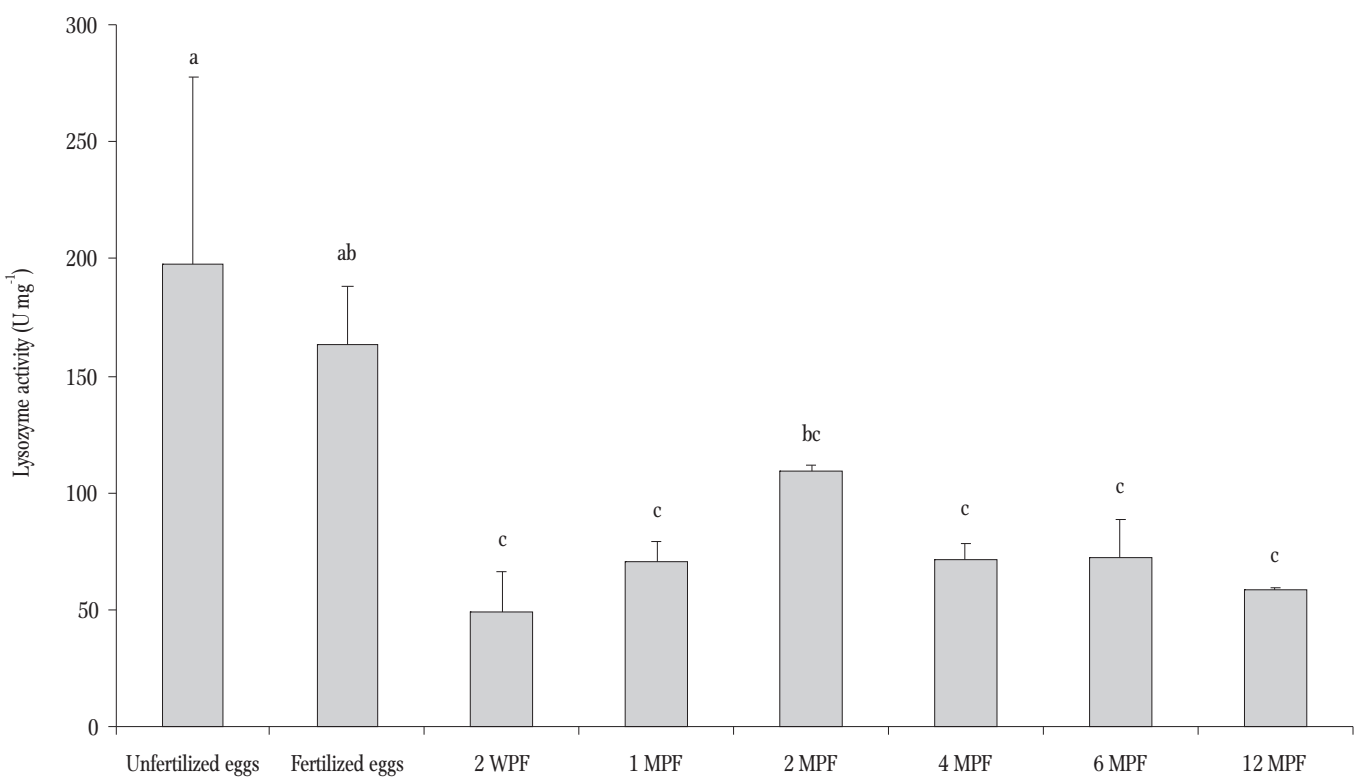

Figure 1. Lysozyme activity in early life stages of Siberian sturgeon (A. baerii). Mean values with different superscripts are significantly different $(\mathrm{P}<0.05)$. WPF, weeks post fertilization; MPF, months post fertilization.

\section{Complement component C3}

The highest significant values of complement component C3 were recorded in unfertilized eggs and 2 MPF juveniles $(\mathrm{P}<0.05)$ (Fig. 3). There were no significant variations of $\mathrm{C} 3$ from fertilized eggs to $1 \mathrm{MPF}$ or from $4 \mathrm{MPF}$ to $12 \mathrm{MPF}(\mathrm{P}<0.05)$. Additionally, the plasma level of $\mathrm{C} 3$ in the female broodstock (3.7 $\pm 0.11 \mathrm{mg} \mathrm{dl}^{-1}$ ) was similar to that of $12 \mathrm{MPF}$ juveniles $(\mathrm{P}<0.05)$.

\section{Discussion}

Fish larvae need to have defensive factors such as lysozyme, IgM, and complement component C3 that play anti-infectious roles before their own defense mechanisms are fully developed. However, sturgeons, like bony fishes, have high mortality rates between yolk sac absorption and exogenous feeding (Mor and Avtalion 1990). Lysozyme has been found in oocytes, fertilized eggs, and larval stages of several species of fish such as in the eggs of Coho salmon 


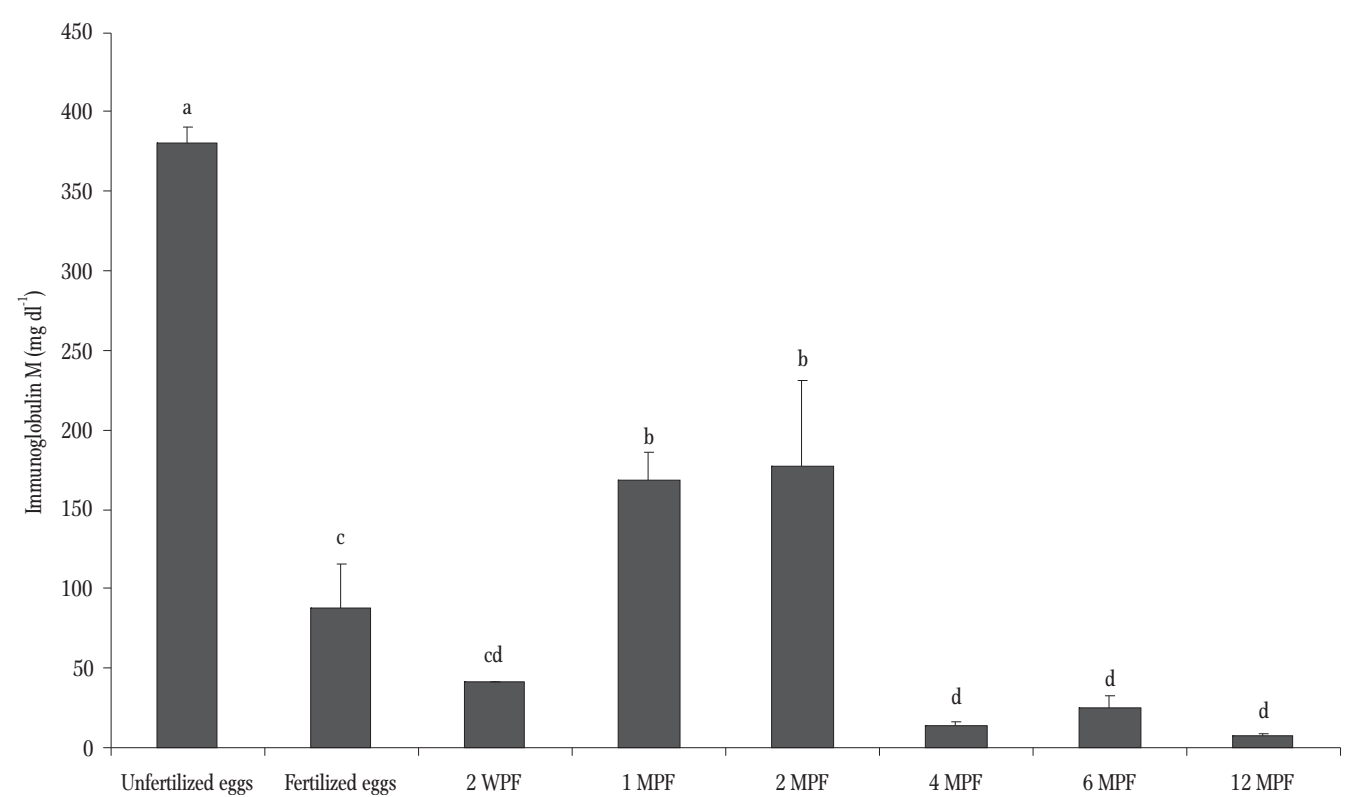

Figure 2. IgM level in early life stages of Siberian sturgeon (A. baerii). Mean values with different superscripts are significantly different (P $<0.05)$. WPF, weeks post fertilization; MPF, months post fertilization.

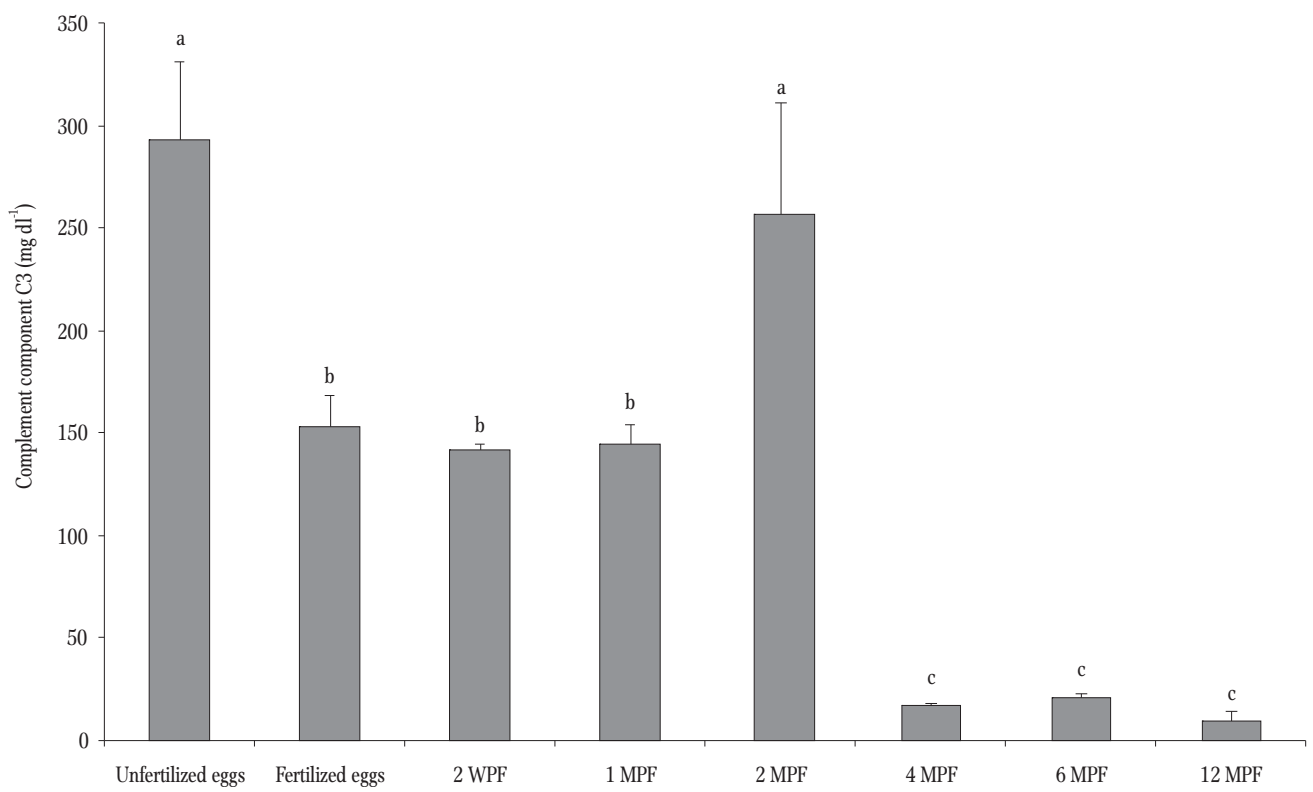

Figure 3. Complement component C3 level in early life stages of Siberian sturgeon (A. baerii). Mean values with different superscripts are significantly different $(\mathrm{P}<0.05)$. WPF, weeks post fertilization; MPF, months post fertilization.

(Yousif et al. 1991), and other salmonids (Yousif et al. 1994), sea bass, (Cecchini et al. 2000), tilapia (Takemura and Takano 1995), and zebrafish, Danio rerio (Hamilton) (Wang and Zhang 2010). Cecchini et al. (2000) showed that the lysozyme in unfertilized eggs was at higher levels than in fertilized eggs (1 HPF) and 6 DPH larvae. In the Caspian Sea, the lowest lysozyme value was recorded in $10 \mathrm{DPH}$ larvae of kutum, Rutilus frisii kutum (Kamensky), in comparison with other early life stages (Abdollahi et al. 2016).

After yolk sac resorption and the start of exogenous feeding, a reduction in lysozyme level was observed in tilapia larvae (Takemura 1993). In the present study, a significant decrease was observed in lysozyme levels from unfertilized eggs to fertilized 
eggs (24 HPF) and $2 \mathrm{WPF}$ larvae. It seems that this reduction could be associated with the absorption of yolk nutrients by embryos and larvae. It has been reported that the yolk sac in the Atlantic sturgeon, Acipenser oxyrinchus Mitchill, disappears during feeding from the environment 14 days after hatching (Gradil et al. 2014). The increment of the lysozyme level in 1-2 MPF juvenile Siberian sturgeon could be because of the completion of the development of the digestive tract and lymphomyeloid tissues. The digestive system of Siberian sturgeon is completed 16-18 DPF when feeding from the environment begins (Gisbert and Williot 1997). Additionally, the appearance of the meningeal myeloid tissue, spleen, and thymus in Acipenserid juveniles is completed 48, 33, and 48 DPH, respectively (Gradil et al. 2014).

IgM is the first immunoglobulin observed during the developmental stages of fertilized eggs (Ingram, 1980). The maternal transfer of IgM has been demonstrated in eggs and embryos of several fish species such as Atlantic salmon, Salmo salar L. (Olsen and Press 1997). In sea bass, maternal IgM is deposited in the ovary during vitellogenesis and reaches maximum concentrations during ovulation. At hatching, this level is reduced by about 100-fold, and no maternal IgM is detected in sea bass $5 \mathrm{DPH}$ (Breuil et al. 1997, Olsen and Press 1997, Pepin et al. 1997, Picchietti et al. 2004). A similar situation is demonstrated in tilapia (Takemura 1993) and Atlantic salmon (Olsen and Press 1997). Pre-larval stages of tilapia, from 0 to $12 \mathrm{DPH}$, show relatively high maternal IgM levels, which gradually decrease to a minimum level at $12 \mathrm{DPH}$ just prior to the maturation of the larval lymphoid organs and autologous IgM production (Takemura 1993). In salmon, maternal IgM levels reduce quickly after hatching and reach levels that are undetectable just prior to the onset of feeding and autologous IgM production (Olsen and Press 1997). Additionally, rainbow trout and channel catfish show the first appearance of surface IgM at about $1 \mathrm{WPH}$ (Petrie-Hansone and Ainsworth 2001).

In Siberian sturgeon, the highest level of IgM was recorded in the unfertilized eggs, which could indicate the maternal transfer of this immune parameter through vitellogenesis. The reduction of IgM in fertilized eggs and 2 WPF larvae could be attributed to the absorption of yolk nutrients by them and the lack of exogenous feeding as well as autologous IgM production. Magnadottir et al. (2005) suggest that the primary role of maternal antibodies is to protect the eggs against a vertical transfer of certain pathogens or that maternal IgM may aid phagocytosis or the activation of complement pathways in early developmental stages; the IgM may even function simply as a nutritional yolk protein. Additionally, maternal IgM can be dispersed throughout the yolk of the egg as well as being localized within the external membrane of the egg as in channel catfish (Hayman and Lobb 1993) and salmon (Olsen and Press 1997), which possibly indicate separate functional roles. The IgM level of Siberian sturgeon showed an increasing trend in larvae older than 14 days until the day 60. It seems that the development of various organs and tissues such as kidney, thymus, and spleen could be effective in increasing the trend of IgM. After $2 \mathrm{MPF}$, the IgM level was significantly decreased, when other immunoglobulins such as IgD (Uribe et al. 2011) are being produced by lymphoid organs and helping body immunity.

The protein C3 is the central component of the complement system and an important factor of the blood, lymphoid organs, and extravascular fluid in all animals (Løvoll et al. 2007). The presence of C3 has been reported in the eggs and embryos of zebrafish (Wang and Zhang 2009), and the Caspian kutum (Abdollahi et al. 2016). The highest and lowest values of C3 were observed in Caspian kutum in $10 \mathrm{DPH}$ larvae and fertilized eggs, respectively (Abdollahi et al. 2016). In spotted wolffish, C3 was identified by Western blotting extracts of unfertilized and newly fertilized eggs that suggested the maternal transfer of the protein to the offspring (Uribe et al. 2011). In Atlantic halibut C3 was detected in the larvae from 5 to 99 days after hatching (Magnadottir et al. 2005, Hermannsdottir et al. 2009). Recent findings suggest that the complement system has important roles in diverse biological processes ranging from early hematopoiesis to skeletal and vascular development, normal reproduction, and limb 
regeneration in lower vertebrates as well as cell and tissue generation in early developmental stages of fish (Mastellos and Lambris 2002, Lange et al. 2004a, 2004b). Quantitative PCR has been performed to detect the onset of C3 transcription in embryos in rainbow trout eggs (Magnadottir et al. 2005). Hence, higher values of complement component C3 than IgM in larval stages of Siberian sturgeon could be linked to the role of this protein in the generation of cells and tissues in early developmental stages. After $2 \mathrm{MPF}$, the C3 level in Siberian sturgeon decreased significantly. It seems that the transmission from sensitive larval stages and the completion of the innate and adaptive immune systems could be important in this decreasing trend. In the present study, there was no significant difference between the immune parameters of the juveniles older than 2 MPF and the plasma of the female broodstock. It seems that Siberian sturgeon attain and immunologically stable condition after 2 MPF and most fluctuations in immune parameters occur up to $2 \mathrm{MPF}$.

\section{Conclusions}

Variations of immune parameters in early life stages of Siberian sturgeon can be divided into three phases: 1 - the unfertilized eggs phase; 2 - the larval phase with endogenous feeding; 3 - the juvenile phase with exogenous feeding. During the first phase, the presence of lysozyme, IgM, and C3 recorded could be attributed to maternal transmission. In the second phase, when the yolk sac is the feeding source absorbed by the larvae, the immune parameters decreased over the two weeks after fertilization. In the third phase, which is concomitant with exogenous feeding and the appearance of immune tissues and the digestive system, levels of lysozyme, IgM, and C3 increased.

Author contributions. B.H. designed the experiment and methods; A.V. and M.H. performed the experiment procedures and analyzed the data; A.Y. prepared the fish samples; A.V. wrote and B.H. corrected the manuscript.

\section{References}

Abdollahi R., Heidari B., Aghamaali M. 2016 - Evaluation of lysozyme, complement C3, and total protein in different developmental stages of Caspian kutum (Rutilus frisii kutum K.) - Arch. Pol. Fish. 24: 15-22.

Alexander J. B., Ingram G.A. 1992 - Noncellular nonspecific defense mechanisms of fish - Annu. Rev. Fish. Dis. 2: 79-249.

Bani A., Banan A. 2010 - Comparison between microsurgery and traditional egg removal from starry sturgeon, Acipenser stellatus, broodstock - J. World. Aquacult. Soc. 4: 144-148.

Bly J.E., Grimm A.S., Morris I.G. 1986 - Transfer of passive immunity from mother to young in a teleost fish: haemagglutinating activity in the serum and eggs of plaice, Pleuronectes platessa L. - Comp. Biochem. Physiol. A. 84: 309-313.

Bradford M.M. 1976 - A rapid and sensitive method for the quantitation of microgram quantities of protein utilizing the principle of protein-dye binding - Anal. Biochem. 72: 248-254.

Breuil G., Vassiloglou B., Pepin J.F., Romestand B. 1997 Ontogeny of IgM-bearing cells and changes in the immunoglobulin M-like protein level (IgM) during larval stages in sea bass Dicentrarchus labrax - Fish Shellfish Immunol.7: 29-43.

Bronzi P., Rosenthal H., Gessner J. 2011 - Global sturgeon aquaculture production: an overview - J. Appl. Ichthyol. 27: 169-175.

Cecchini S., Terova G., Caricato G., Saroglia M. 2000 Lysosome activity in embryos and larvae of sea bass (Dicentrarchus labrax L.), spawned by broodstocks fed with vitamin $\mathrm{C}$ enriched diets - Bull. Eur. Assoc. Fish. Pathol. 20: 120-124.

Chakraborti S., Chatterjee T., Joshi P., Poddar A., Bhattacharyya B., Singh S.P., Gupta V., Chakrabarti P. 2010 - Structure and activity of lysozyme on binding to ZnO Nanoparticles - Langmuir 26: 3506-3513.

Dos Santos N.M.S., Romano N., De Sousa M., Ellis A.E., Rombout J.H.W.M. 2000 - Ontogeny of B and T cells in sea bass (Dicentrarchus labrax L.) - Fish Shellfish Immunol. 10: 583-596.

Ellingsen T., Strand C., Monsen E., Bøgwald J., Dalmo R.A. 2005 - The ontogeny of complement component C3 in the spotted wolffish (Anarhichas minor Olafsen) - Fish Shellfish Immunol. 18: 351-358.

Ellis A.E. 1990 - Lysozyme assays - In: Techniques in Fish Immunology, vol. 1 (Eds) J.S. Stolen, T.C. Fletcher, D.P. Anderson, B.S. Robertson, W.B. Van Muiswinkel, SOS Publications, Fair Haven, USA: 101-103. 
Fearon D.T., Locksley R.M. 1996 - The instructive role of innate immunity in the acquired immune response - Science 272: 50-54.

Gisbert E., Williot P. 1997 - Larval behavior and effect of the timing of initial feeding on growth and survival of Siberian sturgeon (Acipenser baeri) larvae under small scale hatchery production - Aquaculture 156: 63-76.

Gradil A., Wright G., Wadowska D., Fast M. 2014 - Ontogeny of the immune system in Acipenserid juveniles - Dev. Comp. Immunol. 44: 303-314.

Grontvedt R.N., Espelid S. 2003 - Immunoglobulin producing cells in the spotted wolffish (Anarhichas minor Olafsen) - Dev. Comp. Immunol. 27: 569-578.

Hayman J.R., Lobb C.J. 1993 - Immunoglobulin in the eggs of the channel catfish (Ictalurus punctatus) - Dev. Comp. Immunol. 17: 241-248.

Hermannsdottir R., Johannsdottir J., Smaradottir H., Sigurgisladottir S., Gudmundsdottir B. K., Bjornsdottir R. 2009 - Analysis of effects induced by a pollock protein hydrolysate on early development, innate immunity and the bacterial community structure of first feeding of Atlantic halibut (Hippoglossus hippoglossus L.) larvae Fish Shellfish Immunol. 27: 595-602.

Hurley I.A., Mueller R.L., Dunn K.A., Schmidt E.J., Friedman M., Ho R.K., Prince V.E., Yang Z., Thomas M.G., Coates M.I. 2007 - A new time-scale for ray-finned fish evolution - Proc. R. Soc. Lond. Ser. B-Biol. Sci. 274: 489-498.

Ingram G.A. 1980 - Substances involved in the natural resistance of fish to infection - a review - J. Fish Biol. 16: 23-60.

Kumari J., Sahoo P.K., Swain T., Sahoo S.K., Sahu B., Mohanty B.R. 2006 - Seasonal variation in the innate immune parameters of the Asia catfish Clarias batrachus - Aquaculture. 252: 121-127.

Lange S., Bambir S., Dodds A.W., Magnadóttir B. 2004a - An immunohistochemical study on complement component C3 in juvenile Atlantic halibut (Hippoglossus hippoglossus L.) - Dev. Comp. Immunol. 28: 593-601.

Lange S., Bambir S., Dodds A.W., Magnadóttir B. 2004b The ontogeny of complement component C3 in Atlantic cod (Gadus morhua L.) - an immunohistochemical study - Fish Shellfish Immunol. 16: 359-367.

Løvoll M., Johnsen H., Boshra H., Bøgwald J., Sunyer J.O., Dalmo R.A. 2007 - The ontogeny and extrahepatic expression of complement factor C3 in Atlantic salmon (Salmo salar) - Fish Shellfish Immunol. 23: 542-552.

Ludwig A. 2006 - A sturgeon view on conservation genetics Eur. J. Wildl. Res. 52: 3-8.

Magnadottir B., Lange S., Gudmundsdottir S., Bogwald J., Dalmo R. 2005 - Ontogeny of humoral immune parameters in fish - Fish. Shellfish. Immunol. 19: 429-439.

Mastellos D., Lambris J.D. 2002 - Complement: more than a 'guard' against invading pathogens? - Trends Immunol. 23: 485-491.
Mohler J.W., King M.K., Farrell P.R. 2000 - Growth and survival of first-feeding and fingerling Atlantic sturgeon under culture conditions - N. Am. J. Aquacult. 62: 174-183.

Mor A., Avtalion R.R. 1990 - Transfer of antibody activity from immunized mother to embryo in tilapias - J. Fish Biol. 37: 249-255.

Nash J.P., Davail-Cuisset B., Bhattacharyya S., Suter H.C., Le Menn F., Kime D.E. 2000 - An enzyme linked immunosorbant assay (ELISA) for testosterone, estradiol, and 17,20 $\beta$-dihydroxy-4-pregenen-3-one using acetylcholinesterase as tracer: application to measurement of diel patterns in rainbow trout (Oncorhynchus mykiss) - Fish Physiol. Biochem. 22: 355-363.

Olsen Y.A., Press C.Mc.L. 1997 - Degradation kinetics of immunoglobulin in the egg, alevin and fry of Atlantic salmon, Salmo salar L, and the localization of immunoglobulin in the egg - Fish Shellfish Immunol. 7: 81-91.

Pepin J.F., Brueil G., Rigobert P., Romestand B. 1997 - Detection and characterization of immunoglobulins in the eggs of the sea bass Dicentrarchus labrax - Ichtyophysiol. Acta 20: 77-85.

Petrie-Hanson L., Ainsworth A.J. 2001 - Ontogeny of channel catfish lymphoid organs - Vet. Immunol. Immunopathol. 81: 113-127.

Picchietti S., Taddei A.R., Scapigliati G., Buonocore F., Fausto A.M., Romano N., Mazzini M., Mastrolia L., Abelli L. 2004 - Immunoglobulin protein and gene transcripts in ovarian follicles throughout oogenesis in the teleost Dicentrachus labrax - Cell Tissue Res. 315: 259-270.

Sahu A., Lambris J.D. 2001 - Structure and biology of complement protein $\mathrm{C} 3$, a connecting link between innate and acquired immunity - Immunol. Rev. 180: 35-48.

Suzuki Y., Orito M., Furukawa K., Aida K. 1994 - Existence of low molecular weight immunoglobulin $\mathrm{M}$ in carp eggs - Fish. Sci. 60: 159-162.

Takemura A. 1993 - Changes in an immunoglobulin M (IgM)-like protein during larval stages in tilapia, Oreochromis mossambicus - Aquaculture 115: 233-241.

Takemura A. 1996 - Immunohistochemical localization of lysozyme in the prelarvae of tilapia, Oreochromis mossambicus - Fish Shellfish Immunol. 6:75-77.

Takemura A., Takano K. 1995 - Lysozyme in the ovary of tilapia (Oreochromis mossambicus): its purification and some biological properties - Fish Physiol. Biochem. 14: 415-442.

Uribe C., Folch H., Enriquez R., Moran G. 2011 - Innate and adaptive immunity in teleost fish: a review - Vet. Med. 56: 486-503.

Wang Z., Zhang S. 2010 - The role of lysozyme and complement in the antibacterial activity of zebrafish (Danio rerio) egg cytosol - Fish. Shellfish Immunol. 29: 773-777. 
Wang Z., Zhang S., Tong Z., Li L., Wang G. 2009 - Maternal transfer and protective role of the alternative complement components in zebrafish Danio rerio - Plos One, 4: e4498.

Yousif A., Albright L., Evelyn T. 1991 - Occurrence of lysozyme in the eggs of coho salmon Oncorhynchus kisutch - Dis. Aquat. Organ. 10: 45-49.
Yousif A., Albright L., Evelyn T. 1994 - In vitro evidence for the antibacterial role of lysozyme in salmonid eggs - Dis. Aquat. Organ. 19: 15-19. 